\title{
Geographic distribution and genetic diversity of the Ehrlichia sp. from Panola Mountain in Amblyomma americanum
}

\author{
Amanda D Loftis*1,9, Tonya R Mixson ${ }^{1}$, Ellen Y Stromdahl ${ }^{2}$, \\ Michael J Yabsley 3,4 , Laurel E Garrison ${ }^{5}$, Phillip C Williamson', \\ Robert R Fitak ${ }^{7}$, Paul A Fuerst ${ }^{7}$, Daryl J Kelly ${ }^{7}$ and Keith W Blount ${ }^{8}$
}

\begin{abstract}
Address: ${ }^{1}$ Centers for Disease Control and Prevention, Atlanta, GA 30333, USA, ${ }^{2}$ U.S. Army Center for Health Promotion and Preventive Medicine, Entomological Sciences Program, Aberdeen Proving Ground, MD 21010-5403, USA, ${ }^{3}$ Daniel B. Warnell School of Forestry and Natural Resources, University of Georgia, Athens, GA 30602, USA, ${ }^{4}$ Southeastern Cooperative Wildlife Disease Study, Department of Population Health, College of Veterinary Medicine, University of Georgia, Athens, GA 30602, USA, ${ }^{5}$ Georgia Division of Public Health, Atlanta, GA 30303-3186, USA, ${ }^{6}$ NA/ Identity Laboratory, Department of Pathology and Human Identification, University of North Texas Health Science Center, Ft. Worth, TX 761072699, USA, 7 Department of Evolution, Ecology and Organismal Biology, The Ohio State University, Columbus, OH 43210-1293, USA, ${ }^{8}$ Air Force Research Laboratory, Brooks City-Base, TX 78235, USA and ${ }^{9} 266$ N. Lincoln St., Laramie, WY 82070, USA
\end{abstract}

Email: Amanda D Loftis* - adloftis@gmail.com; Tonya R Mixson - zdy0@cdc.gov; Ellen Y Stromdahl - ellen.stromdahl@us.army.mil; Michael J Yabsley - myabsley@vet.uga.edu; Laurel E Garrison - legarrison@dhr.state.ga.us; Phillip C Williamson - phwilliam@hsc.unt.edu; Robert R Fitak - fitak.2@osu.edu; Paul A Fuerst - fuerst.1@osu.edu; Daryl J Kelly - kelly.350@osu.edu; Keith W Blount - keith.blount@brooks.af.mil

* Corresponding author

\section{Published: 23 April 2008}

BMC Infectious Diseases 2008, 8:54 doi:10.1 I86/I47|-2334-8-54
Received: 9 November 2007

Accepted: 23 April 2008

This article is available from: http://www.biomedcentral.com/I47/-2334/8/54

(c) 2008 Loftis et al; licensee BioMed Central Ltd.

This is an Open Access article distributed under the terms of the Creative Commons Attribution License (http://creativecommons.org/licenses/by/2.0), which permits unrestricted use, distribution, and reproduction in any medium, provided the original work is properly cited.

\begin{abstract}
Background: A novel Ehrlichia, closely related to Ehrlichia ruminantium, was recently discovered from Panola Mountain State Park, GA, USA. We conducted a study to determine if this agent was recently introduced into the United States.

Methods: We developed a sensitive PCR assay based on the conserved gltA (citrate synthase) gene and tested DNA samples extracted from 1964 field-collected and 1835 human-biting Amblyomma americanum from 23 eastern states of the USA.

Results: The novel agent was detected in 36 ticks collected from 10 states between 1998 and 2006. Infected ticks were collected both from vegetation $(n=14,0.7 \%)$ and from humans $(n=22$, I.2\%). Fragments of the conserved gltA gene and the variable mapl gene were sequenced from positive samples. Two distinct clades, with $10.5 \%$ nucleic acid divergence over the 730 bp map I sequence, were identified.

Conclusion: These data suggest that the Panola Mountain Ehrlichia was not recently introduced to the United States; this agent has an extensive distribution throughout the range of its tick vector, has been present in some locations for several years, and displays genetic variability. Furthermore, people in several states were exposed to this agent through the bite of infected ticks, underscoring the potential public health risk of this emerging ehrlichiosis.
\end{abstract}




\section{Background}

A novel Ehrlichia transmitted by Amblyomma americanum (lone star ticks) was recently discovered in Panola Mountain State Park, Georgia, USA. The "Panola Mountain Ehrlichia" (PME), which is closely related to E. ruminantium, caused transient febrile illness, followed by chronic latent infection, in a goat [1]. This agent was also associated, using PCR and sequencing, with a case of human illness following a bite from a nymphal Amblyomma acquired at Panola Mountain State Park [2]. White-tailed deer (Odocoileus virginanus) are a probable vertebrate reservoir for PME in the United States; deer are susceptible to infection, are naturally exposed to the agent, and are competent reservoirs for tick transmission of this agent [3].

Ehrlichia ruminantium is endemic in southern Africa and the Caribbean, and its pathogenicity in cattle, sheep, and goats varies from mild febrile illness to fatal heartwater [47]. Several species of Amblyomma vector E. ruminantium in Africa and A. variegatum is the vector in the Caribbean [4]. This exotic disease has not been detected in the United States, but it could be introduced into the country by the importation of animals and tick vectors from endemic areas $[8,9]$. White-tailed deer are also susceptible to infection with E. ruminantium [10], and could provide a sylvatic reservoir for E. ruminantium in the United States. Thus, the Ehrlichia discovered at Panola Mountain State Park could be a divergent strain of E. ruminantium that was recently introduced to this country. This park is located within the Atlanta, Georgia, metropolitan area and is less than twenty miles from the Hartsfield International Airport, a port of entry for imported animals and animal products.

To evaluate the geographic distribution and public health risk posed by this emerging agent, we developed a sensitive nested PCR assay based on the gltA (citrate synthase) gene, which is conserved within species of Ehrlichia [11], and screened DNA extracts from A. americanum collected from vegetation and submitted through four different human-biting tick surveillance programs. All PCR amplicons were confirmed by sequencing the gltA fragment, and the genetic diversity of this novel agent was evaluated by amplification and sequencing of the variable Major Antigenic Protein 1 gene (map1) [12].

\section{Methods}

\section{Collection of ticks}

Ticks were collected in the years 1998-2006. Questing ticks were collected by flagging vegetation or by using carbon dioxide baited traps, as described by Fleetwood et al. [13]. Ticks removed from humans were collected through surveillance programs established by the Georgia Division of Public Health, Ohio Department of Health, University of North Texas Health Science Center, and U.S. Army
Center for Health Promotion and Preventive Medicine. Ticks were voluntarily submitted by individuals who reported the location in which they believed the tick was acquired. All ticks were identified to species and life stage, and gender of adult ticks was recorded. DNA was extracted from individual questing adult ticks as previously described $[1,14]$. For human-biting tick collections, DNA was extracted from individual nymphal and adult ticks, or from pools of ticks collected from a single person, using previously described methods [15].

\section{PCR detection of PME}

A nested PCR assay for the Panola Mountain Ehrlichia was designed based on the published gltA sequence (GenBank:DQ363995). Nested PCR primers were designed using Primer Express 2.0 (Applied Biosystems, Foster City, CA) and GCG Seqlab (Accelrys, San Diego, CA), and evaluated for specificity using a panel of DNA from A. americanum known to be PCR-positive for the agent and negative DNA samples extracted from colony-reared ticks. Sensitivity was determined using a cloned plasmid containing the gltA gene from the Ehrlichia sp. Reaction conditions were optimized to ensure a sensitivity of at least 10 gene copies. The outer PCR reaction included $5.0 \mu \mathrm{L}$ of Taq Master Mix (Qiagen, Valencia, CA), $500 \mathrm{nM}$ each of primers Ehr3CS-185F (5'-GCC ACC GCA GAT AGT TAG GGA) and Ehr3CS-777R (5'-TTC GTG CTC GTG GAT CAT AGT TTT), and $1.0-2.0 \mu \mathrm{L}$ of DNA in a $10 \mu \mathrm{L}$ final reaction volume. The volume of DNA used in each reaction was based upon the elution volume of DNA; $1.0 \mu \mathrm{L}$ was used for DNA samples in a final volume of $50-100 \mu \mathrm{L}$, and 2.0 $\mu \mathrm{L}$ were used for samples extracted in a volume of $200 \mu \mathrm{L}$. The thermocycler program was as follows: $95^{\circ} \mathrm{C}$ for 3 min, followed by 40 cycles of $95^{\circ} \mathrm{C}$ for $30 \mathrm{sec}, 55^{\circ} \mathrm{C}$ for $30 \mathrm{sec}$, and $72^{\circ} \mathrm{C}$ for $60 \mathrm{sec}$, with a final extension at $72^{\circ} \mathrm{C}$ for $5 \mathrm{~min}$. The inner PCR reaction included $10.0 \mu \mathrm{L}$ of Taq Master Mix, $500 \mathrm{nM}$ each of primers Ehr3CS-214F (5'-TGT CAT TTC CAC AGC ATT CTC ATC) and Ehr3CS-619R (5'TGA GCT GGT CCC CAC AAA GTT), and $1.5 \mu \mathrm{L}$ of the primary reaction product in a $20 \mu \mathrm{L}$ final reaction volume. The thermocycler program was similar to the primary reaction, but with a $60^{\circ} \mathrm{C}$ annealing temperature rather than $55^{\circ} \mathrm{C}$.

All PCR reactions were prepared in a dedicated hood equipped with an ultraviolet light source. Positive (10 copy) and negative controls were included on every plate; positive control material was handled only after all unknown samples were loaded. Ticks that were identified as positive using the gltA primer set were confirmed by repeating the assay and by sequencing. Positive ticks were tested using a PCR assay for map1, as previously described $[1,16]$, using the outer primer pair map1-forward/map1reverse and, if needed, paired heminested reactions with 


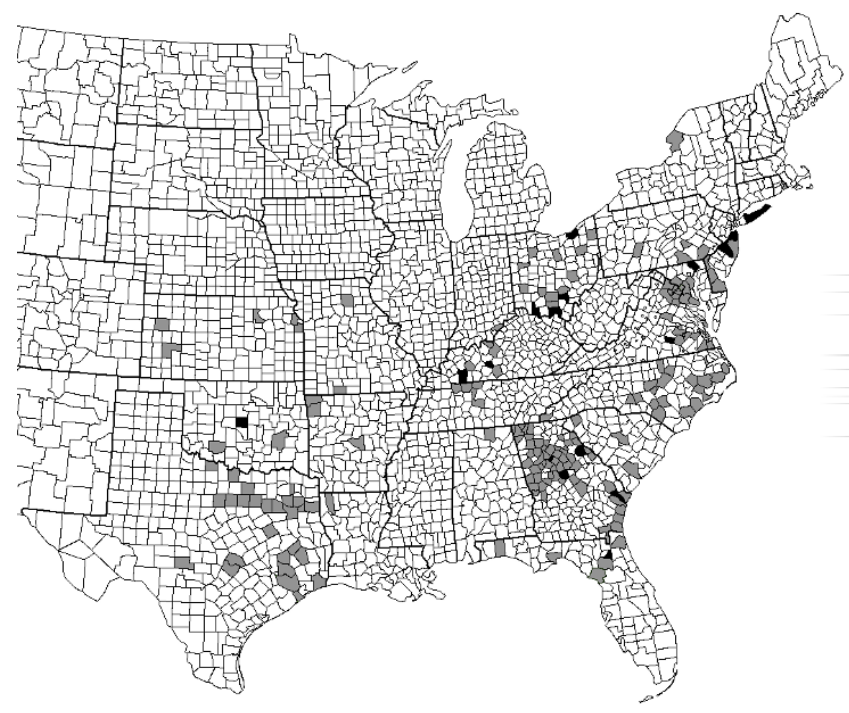

Figure I

Geographic distribution of the Panola Mountain Ehrlichia sp. Summary of collection sites for Amblyomma americanum, by county. Counties from which ticks were tested and PME was not detected are shaded gray $(n=185)$; counties from which at least one tick contained DNA from PME are shaded black $(n=18)$. In addition to the counties listed in Table 3, Rockdale County, Georgia, which contains Panola Mountain State Park, is shaded black.

Pmap-2F/map1-reverse and map1-forward/Pmap-2R or nested reactions with Pmap-2F/Pmap-2R.

\section{Sequence analysis}

All PCR amplicons obtained using the gltA assay and map1 assay were sequenced, with 2- to 4 - fold coverage, using PCR primers. When mixed sequences were obtained, PCR amplicons were cloned using TOPO TA Cloning kits with the pCR 2.1-TOPO vector (Invitrogen, Carlsbad, CA) and sequencing was repeated using several clones. Fragments were assembled using GCG Seqmerge (Accelrys), translated into the respective predicted amino acid sequences, and aligned. All sequences were submitted to GenBank: gltA, EU272374-EU272410 and map1, EU272339EU272373. Related sequences were identified using BLAST (NCBI, Bethesda, MD). Phylogenetic reconstructions based on the amino acid sequences of the map1 amplicons were performed using PAUP 4.0 Beta 10 (Sinauer Asosciates, Inc., Sunderland, MA). The most parsimonious trees were constructed using heuristic bootstrap analysis (1000 replicates); starting trees were obtained by stepwise addition with tree-bisection-reconnection as the branch-swapping algorithm.
Table I: Summary of test results for ticks collected from vegetation. Amblyomma americanum adults were collected from vegetation and tested for the presence of the Panola Mountain Ehrlichia sp.

\begin{tabular}{|c|c|c|c|}
\hline Collection State & \# Ticks (M/F) & \# POS (M/F) & $\%$ POS \\
\hline Florida & I5I (57/94) & I $(1 / 0)$ & $0.66 \%$ \\
\hline Georgia & $705(292 / 4 \mid 3)$ & $6(3 / 3)$ & $0.85 \%$ \\
\hline Kentucky & $6(1 / 5)$ & $\mathrm{I}(0 / \mathrm{I})$ & $16.7 \%$ \\
\hline New Jersey & $120(68 / 52)$ & $2(2 / 0)$ & $1.67 \%$ \\
\hline New York & $475(246 / 229)$ & $4(4 / 0)$ & $0.84 \%$ \\
\hline North Carolina & $383(152 / 231)$ & 0 & $0 \%$ \\
\hline South Carolina & $80(37 / 43)$ & 0 & $0 \%$ \\
\hline Texas & $44(14 / 30)$ & 0 & $0 \%$ \\
\hline TOTAL & $1964(867 / / 097)$ & $14(10 / 4)$ & $0.71 \%$ \\
\hline
\end{tabular}

Results are summarized here by state of collection and gender $(M=$ male, $F=$ female).

\section{Results and Discussion}

Amblyomma americanum were collected from 203 counties in 23 states, representing much of the geographic range of this tick (Figure 1).

Questing ticks were collected from vegetation at 32 sites in 8 states. Of 1964 questing adult ticks, including 867 adult males and 1097 adult females, 14 ticks (10 males, 1.15\%, and 4 females, $0.36 \%$ ) were positive for PME (Table 1 ). The overall prevalence of infection in questing ticks was $0.71 \%$, and the prevalence of infection in sites with infected ticks ranged from $1.32-2.88 \%$.

Human-biting ticks were obtained, via surveillance programs, from 21 states. Of 1835 A americanum obtained from surveys of human-biting ticks, 22 DNA samples from 5 states were positive (Table 2). Six of these positive samples were pools of 2-9 ticks, with the remainder representing individual ticks. Given the low prevalence of infection, we assumed that only one tick in a positive pool was likely to be positive; the infection rate among humanbiting ticks was therefore 22/1835, or $1.20 \%$. Eleven of the positive samples were from nymphal ticks $(1.12 \%)$, three from males $(0.71 \%)$, five from females $(1.17 \%)$, and five from pools containing more than one life stage.

Overall, 35 positive ticks were obtained from 18 counties in ten states: Florida, Georgia, Kentucky, Maryland, Missouri, New Jersey, New York, Ohio, Oklahoma, and Virginia (Figure 1). Four of these ticks were co-infected with E. chaffeensis and/or E. ewingii (Table 3). None of the positive ticks were co-infected with "Borrelia lonestari". All of the positive ticks were collected between the months of April and September. Positive ticks were identified from collections made in 1998 through 2006; on Fire Island, in Suffolk Co., New York, individual positive ticks were collected from vegetation in both 1998 and 
Table 2: Summary of test results for human-biting ticks. Amblyomma americanum nymphs and adults were collected from human-biting tick surveillance programs and tested for the presence of the Panola Mountain Ehrlichia sp. Results are summarized here by the state of reported tick acquisition and life stage or gender $(N=$ nymph, $M=$ male, $F=$ female $)$.

\begin{tabular}{|c|c|c|c|}
\hline Collection State & \# Ticks (N/M/F/Not Recorded) & \# POS (N/M/F/unknown)a & $\%$ POS \\
\hline Alabama & $8(2 / 2 / 4 / 0)$ & 0 & \\
\hline Arkansas & $8(1 / 2 / 4 / 1)$ & 0 & \\
\hline District of Columbia & $7(1 / 3 / 3 / 0)$ & 0 & \\
\hline Delaware & $12(8 / 2 / 2 / 0)$ & 0 & \\
\hline Florida & $7(3 / 2 / 1 / 1)$ & 0 & \\
\hline Georgia & $343(157 / 87 / 98 / 1)$ & 0 & \\
\hline Indiana & $\mathrm{I}(\mathrm{I} / 0 / 0 / 0)$ & 0 & \\
\hline Kansas & $67(32 / 12 / 22 / 1)$ & 0 & \\
\hline Kentucky/Tennessee & $199(114 / 40 / 45 / 0)$ & $\mathrm{I}(0 / 0 / \mathrm{I} / 0)$ & $0.50 \%$ \\
\hline Louisiana & $\mathrm{I}(\mathrm{I} / 0 / 0 / 0)$ & 0 & \\
\hline Maryland & $266(|78 / 5| / 37 / 2)$ & $4(3 / 1 / 0 / 0)$ & $1.50 \%$ \\
\hline Missouri & $10(3 / 3 / 4 / 0)$ & $\mathrm{I}(0 / 0 / \mathrm{I} / 0)$ & $10.0 \%$ \\
\hline North Carolina & $93(45 / 25 / 23 / 0)$ & 0 & \\
\hline Nebraska & $\mathrm{I}(\mathrm{I} / 0 / 0 / 0)$ & 0 & \\
\hline New Jersey & $265(163 / 57 / 45 / 3)$ & $7\left(3 / 1 / 1 / 2^{a}\right)$ & $2.64 \%$ \\
\hline New York & $\mathrm{I}(\mathrm{I} / 0 / 0 / 0)$ & 0 & \\
\hline Ohio & $22(11 / 7 / 4 / 0)$ & $6(3 / 1 / 2 / 0)$ & $27.3 \%$ \\
\hline Oklahoma & $21(14 / 3 / 3 / 1)$ & $\mathrm{I}\left(0 / 0 / 0 / \mathrm{I}^{\mathrm{a}}\right)$ & $4.76 \%$ \\
\hline Pennsylvania & $4(1 / 1 / 2 / 0)$ & 0 & \\
\hline Rhode Island & $\mathrm{I}(0 / 0 / 1 / 0)$ & 0 & \\
\hline South Carolina & $33(17 / 7 / 9 / 0)$ & 0 & \\
\hline Texas & $81(23 / 32 / 26 / 0)$ & 0 & \\
\hline Virginia & $368(199 / 80 / 89 / 0)$ & $\mathrm{I}(\mathrm{I} / 0 / 0 / 0)$ & $0.27 \%$ \\
\hline Unknown/Unrecorded & $16(7 / 5 / 4 / 0)$ & $\mathrm{I}(\mathrm{I} / 0 / 0 / 0)$ & $6.25 \%$ \\
\hline TOTAL & $1835(983 / 421 / 426 / 10)$ & $22(11 / 3 / 5 / 3)$ & $1.20 \%$ \\
\hline
\end{tabular}

a: When a pool of ticks (2-9 ticks each) was positive, the minimum infection rate ( 1 tick) is reported. The life stage of the infected tick could not be determined for 3 pools that included more than one life stage.

b: Kentucky and Tennessee ticks were combined, since most of the ticks in this collection centered on the border between these two states.

2003, suggesting that the agent was maintained in this area over several years. Similarly, positive human-biting ticks in Burlington Co., New Jersey were collected in 2001 and 2006, and ticks collected from Scioto Co., Ohio in 2000 and 2001 were positive.

The nested gltA amplicon was sequenced from all positive ticks. All positive amplicons had sequences consistent with PME; E. chaffeensis or E. ewingii were not amplified. The gltA sequence was highly conserved and was identical to the reported PME sequence (GenBank: DQ363995) in 35/36 ticks; one sequence included a single nucleotide polymorphism (EU272407).

A portion of map1 was successfully amplified and sequenced from 31 of the 36 positive tick DNA samples; the outer PCR amplicon, when available, produced 730 bp of sequence, and the inner amplicon produced $384 \mathrm{bp}$. Two map1 genogroups were identified and were seen both in questing ticks and in human-biting ticks (Table 3): one group was $100 \%$ homologous to the sequence reported from PME (GenBank:DQ324368), and the other group was $89.5 \%$ similar to PME, with two polymorphic loci identified within this group of sequences. There were five base pair mismatches between the sequences in the latter genogroup and the outer pair of PCR primers previously developed for the detection of the map1 gene from this agent (Pmap-38F/Pmap-581R, [1]). The two different PME clades were not geographically isolated; both clades were detected in ticks from Jones County, Georgia and Monmouth County, New Jersey. Additionally, one pool of ticks from Ocean County, New Jersey, contained both genotypes. The amplicons produced from this mixed template pool were cloned and sequenced. Sequence analysis indicated representatives of both genotypes were present, as well as several sequences that appear to be combinations of these two genotypes and may indicate a crossover event in map1 (GenBank: EU272356-EU272360).

Phylogenetic reconstructions based on the map 1 amino acid sequences were attempted (Figure 2) using all of the DNA sequences that were $730 \mathrm{bp}$ in length. The sequences from the ticks formed two distinct clades, with 100\% bootstrap support for each clade (1000 psuedoreplicates), and they formed a cluster within the larger taxonomic group of E. ruminantium strains in $82 \%$ of the replicates. 
Table 3: Collection details and map I sequence homologies of the positive ticks. Collection details for the 36 Amblyomma americanum harboring DNA from the Panola Mountain Ehrlichia sp. (PME) are shown, including the source of the tick, date of collection, coinfectionn status, and homology of the mapI DNA amplicons to reference sequences for PME.

\begin{tabular}{|c|c|c|c|c|c|c|c|}
\hline \multicolumn{2}{|c|}{$\begin{array}{l}\text { Location Tick Was Collected } \\
\text { or Acquired }\end{array}$} & \multirow{2}{*}{$\begin{array}{l}\text { Collected } \\
\text { From }\end{array}$} & \multirow{2}{*}{$\begin{array}{l}\text { Life Stage } \\
M\end{array}$} & \multirow{2}{*}{$\begin{array}{l}\text { Date } \\
\text { Collected }\end{array}$} & \multirow[t]{2}{*}{$\begin{array}{l}\text { Coinfection with } \\
\text { Other Ehrlichia }\end{array}$} & \multirow{2}{*}{$\begin{array}{l}\text { mapI GenBank } \\
\text { Sequence ID } \\
\text { EU272339 }\end{array}$} & \multirow{2}{*}{$\begin{array}{l}\text { mapl Homol- } \\
\text { ogy }^{\mathbf{a}}\end{array}$} \\
\hline $\mathrm{FL}$ & Bradford Co. & & & & & & \\
\hline \multirow[t]{6}{*}{ GA } & Jones Co. & vegetation & $\mathrm{F}$ & $6 / 9 / 2003$ & & EU272340 & $730 / 730$ \\
\hline & Jones Co. & vegetation & $M$ & $6 / 9 / 2003$ & & EU272341 & $654 / 730$ \\
\hline & Jones Co. & vegetation & $M$ & $6 / 9 / 2003$ & & $\overline{\text { EU } 272342}$ & $654 / 730$ \\
\hline & Wilkes Co. & vegetation & $M$ & $6 / 11 / 2004$ & & EU272343 & $730 / 730$ \\
\hline & Wilkes Co. & vegetation & $\mathrm{F}$ & $6 / 11 / 2004$ & & EU272344 & $730 / 730$ \\
\hline & Bryan Co. & vegetation & $\mathrm{F}$ & $6 / 18 / 2004$ & & $\overline{\text { EU272345 }}$ & $730 / 730$ \\
\hline \multirow[t]{2}{*}{ KY } & Edmonson Co. & vegetation & $\mathrm{F}$ & $6 / 30 / 2002$ & & EU272346 & $654 / 730$ \\
\hline & Christian Co. & 22 yo female & $2 \mathrm{FF}$ & $6 / 13 / 2006$ & & EU272347 & $654 / 730$ \\
\hline \multirow[t]{4}{*}{ MD } & Harford Co. & 20 yo male & $\mathrm{N}$ & $7 / 18 / 2001$ & & EU272348 & $384 / 384^{b}$ \\
\hline & Harford Co. & 52 yo male & $\mathrm{N}$ & $5 / 3 \mid / 2006$ & & EU272349 & $730 / 730$ \\
\hline & Harford Co. & 25 yo male & $M$ & $6 / 7 / 2006$ & & EU272350 & $730 / 730$ \\
\hline & Harford Co. & 50 yo male & $9 \mathrm{NN}$ & $6 / 28 / 2006$ & E. ewingii & no amplification & \\
\hline MO & Not recorded & humanc & $\mathrm{F}$ & $6 / 23 / 2000$ & & no amplification & \\
\hline \multirow[t]{9}{*}{ NJ } & Burlington Co. & 35 yo male & $\mathrm{N}$ & $6 / 29 / 2001$ & & EU27235I & $384 / 384^{b}$ \\
\hline & Burlington Co. & 34 yo male & $\mathrm{F}$ & $6 / 29 / 2001$ & & EU 272352 & $277 / 277^{b}$ \\
\hline & Monmouth Co. & vegetation & $\mathrm{F}$ & $4 / 22 / 2003$ & $\begin{array}{l}\text { E. ewingii } E \text {. } \\
\text { chaffeensis }\end{array}$ & EU272353 & $654 / 730$ \\
\hline & Monmouth Co. & vegetation & $\mathrm{F}$ & $4 / 22 / 2003$ & & EU272354 & $730 / 730$ \\
\hline & Ocean Co. & 41 yo male & $M+N$ & $5 / 22 / 2006$ & E. chaffeensis & EU272355 & $654 / 730$ \\
\hline & Ocean Co. & 46 yo male & $\mathrm{F}+\mathrm{N}$ & $6 / 27 / 2006$ & & $\begin{array}{l}\text { EU272356- } \\
\text { EU272360 }\end{array}$ & $\begin{array}{l}730 / 730,654 / \\
730^{d}\end{array}$ \\
\hline & Burlington Co. & 41 yo male & $M$ & $7 / 20 / 2006$ & & $\overline{\text { EU27236I }}$ & $730 / 730$ \\
\hline & Burlington Co. & 31 yo male & $\mathrm{N}$ & $7 / 20 / 2006$ & & $\overline{\text { EU } 272362}$ & $730 / 730$ \\
\hline & Burlington Co. & 46 yo male & $2 \mathrm{NN}$ & $8 / 1 / 2006$ & & EU272363 & $730 / 730$ \\
\hline \multirow[t]{4}{*}{ NY } & Suffolk Co. & vegetation & $M$ & $7 / 3 / 1998$ & $\begin{array}{l}\text { E. ewingii } E \text {. } \\
\text { chaffeensis }\end{array}$ & EU272364 & $730 / 730$ \\
\hline & Suffolk Co. & vegetation & $M$ & $6 / 4 / 2003$ & & EU272365 & $730 / 730$ \\
\hline & Suffolk Co. & vegetation & $M$ & $6 / 4 / 2003$ & & EU272366 & $730 / 730$ \\
\hline & Suffolk Co. & vegetation & $M$ & $7 / 9 / 2003$ & & $\overline{\text { EU272367 }}$ & $730 / 730$ \\
\hline \multirow[t]{6}{*}{$\mathrm{OH}$} & Scioto Co. & humanc & $\mathrm{F}$ & $5 / 8 / 2000$ & & $\overline{\text { EU272368 }}$ & $377 / 377^{b}$ \\
\hline & Clermont Co. & humanc & $M$ & $5 / 30 / 2000$ & & EU272369 & $384 / 384^{b}$ \\
\hline & Cuyahoga Co. & humanc & $\mathrm{F}$ & $6 / 7 / 2000$ & & EU272370 & $375 / 375^{b}$ \\
\hline & Vinton Co. & humanc & $\mathrm{N}$ & $6 / 23 / 2000$ & & $\overline{\text { no amplification }}$ & \\
\hline & Hocking Co. & humanc & $\mathrm{N}$ & $9 / 13 / 2000$ & & EU272371 & $376 / 377^{b}$ \\
\hline & Scioto Co. & humanc & $\mathrm{N}$ & $6 / 27 / 2001$ & & EU272372 & $313 / 313^{b}$ \\
\hline OK & Oklahoma Co. & humanc & $\mathrm{F}+7 \mathrm{NN}$ & $7 / 25 / 2006$ & & $\overline{\text { EU272373 }}$ & $730 / 730$ \\
\hline VA & Nottoway Co. & 25 yo male & $\mathrm{N}$ & $6 / 27 / 2006$ & & $\overline{\text { no amplification }}$ & \\
\hline \multicolumn{2}{|c|}{ State not recorded } & humanc & $\mathrm{N}$ & $5 / 23 / 2000$ & & no amplification & \\
\hline
\end{tabular}

a: Percent homology to the reference sequence for PME, GenBank: DQ324368

b: Only the internal, nested fragment was available for sequencing.

c: Age and gender not recorded.

d: The mapI PCR amplicon was a mixture of more than one sequence, and the product was cloned prior to sequencing.

The PME/E. ruminantium clade was a sister taxa to $E$. chaffeensis and E. canis in $100 \%$ of the replicates. Bootstrap support for separation of PME and E. ruminantium into separate taxa was weak $(<500 / 1000)$.

\section{Conclusion}

We detected the novel Panola Mountain Ehrlichia sp. (PME), recently discovered in A. americanum from north central Georgia, USA, in 36 ticks from 18 counties in ten states. DNA from PME was detected in ticks from the tra- ditional southeastern range of $A$. americanum as well as from recently established populations in the northeastern USA. The overall prevalence of infection with PME, approximately $1-3 \%$, was similar to that previously reported from Panola Mountain [1]. Similar prevalences of E. ewingii and E. ruminantium are seen in populations of Amblyomma infected with these agents [14,17-19].

Earlier assays for PME were based on the gene encoding the Major Antigenic Protein 1 (map1) [1]; this gene can be 


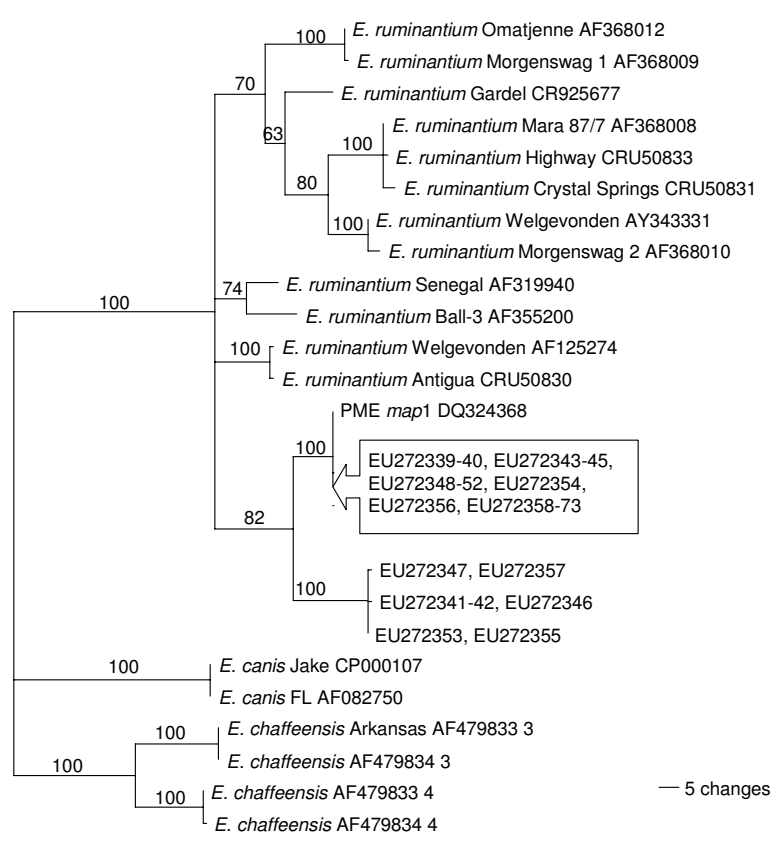

Figure 2

Genetic diversity of the Panola Mountain Ehrlichia sp. Phylogenetic reconstruction of the mapl predicted amino acid sequences from 3 I Amblyomma americanum harboring DNA from the Panola Mountain Ehrlichia sp. (PME). Numbers indicate the bootstrap support for each node, as a percentage of 1000 replicates, and the scale represents the number of changes per 100 residues.

highly variable [12], and polymorphisms in the primer annealing sites could prevent the detection of some genotypes of PME. We therefore developed a sensitive and specific nested PCR assay based on the conserved gltA gene. As expected, gltA amplicons obtained from PME-infected ticks were $99.5-100 \%$ identical to each other and to the sequence previously reported from this agent. Significant mismatches were seen between the previously reported map1 primers and the map1 sequences from PME-infected ticks. Additionally, map1 could not be amplified from all of the gltA-positive ticks, presumably due to primer site mismatches, confirming that detection of PME using map1 assays is limited by the variability of this gene.

This gene is, however, a valuable tool to assess genetic variability in PME across the geographic range of A. americanum. Using phylogenetic reconstruction of map1 sequences, we identified two clades, one of which includes the genotype previously reported from Panola Mountain. Both PME clades were closely associated with each other and were more closely related to E. ruminantium than to any other species of Ehrlichia, similar to previous reports. Sequences that suggest the possibility of crossover between these two genotypes were also obtained from a few clones from a single DNA sample; collection and analysis of other specimens, to determine if this is an isolated finding, are ongoing.

The extensive geographic distribution of PME and the presence of genetic variability within the species suggest that this agent was not recently introduced to the United States. A recent point source introduction should have resulted in a limited geographic distribution of a single genotype or possibly of closely related genotypes with minimal divergence. Although two distinct genotypes of PME were detected, less genetic diversity was seen than is reported to occur between African strains of E. ruminantium, suggesting that the map1 gene of PME might evolve more slowly than that of its African counterparts, that the diversity of susceptible Amblyomma and vertebrate species in Africa might have contributed to the diversity of $E$. ruminantium on that continent, or that the introduction of E. ruminantium-like bacteria to North America might have been more recent than the introduction into Africa.

Finally, the lack of reports of heartwater, or heartwaterlike disease, in ruminants, wild or domestic, from areas in which PME was detected provides indirect support that this agent has low pathogenicity for these animals. However, this emerging ehrlichiosis has been associated with a human case of illness following the bite of a nymphal $A$. americanum from Panola Mountain State Park. Amblyomma americanum is an abundant and aggressive humanbiting tick throughout its geographic range [20]. Our detection of PME in 22 human-biting ticks underscores the potential public health risk of this emerging tick-transmitted disease. The broad geographic range and patchy distribution of ticks harboring PME suggests that human cases could occur throughout the eastern United States but be sporadic in nature and therefore difficult to diagnose. Sensitive and specific PCR assays, performed on whole blood samples collected during the acute febrile period, might assist in the rapid clinical diagnosis of undifferentiated ehrlichial infections in people with a history of tick bite by A. americanum.

\section{Competing interests}

The authors declare that they have no competing interests.

\section{Authors' contributions}

AL conceived of the study, carried out portions of the molecular genetic studies, participated in the sequence alignment and analysis, performed statistical analysis, and drafted the manuscript. TM, ES, and KB participated in the design of the study, collected tick samples, carried out portions of the molecular genetic studies, and helped to draft the manuscript. PW participated in the design of the study, collected tick samples, carried out portions of the molecular genetic studies, participated in the sequence 
analysis, and helped to draft the manuscript. MY and RF carried out portions of the molecular genetic studies, participated in the sequence alignment, and helped to draft the manuscript. LG, PF, and DK participated in the design of the study, collected tick samples, and helped to draft the manuscript. All authors read and approved the final manuscript.

\section{Acknowledgements}

We thank Tracy Lambert-Jack, Mike Santeriello, Kerri Harding, Lisa Roeper, Rich Brush, Raul Perez, Ellen Montgomery, Joe Tardio, Ruth Carroll, and Ralph Narain, and Gaylord Lopez for assistance with tick collection and Kimetha Slater, Mason Y. Savage, and Peggy M. Billingsley for laboratory support. The findings and conclusions in this report are those of the authors and do not necessarily represent the official policy or position of the Centers for Disease Control and Prevention, United States Depart-

ment of Health and Human Services, Department of the Army, Department of Defense, or the U.S. Government.

\section{References}

I. Loftis AD, Reeves WK, Spurlock JP, Mahan SM, Troughton DR, Dasch GA, Levin ML: Infection of a goat with a tick-transmitted Ehrlichia from Georgia, U.S.A. that is closely related to Ehrlichia ruminantium. J Vector Ecol 2006, 31:213-223.

2. Bell JR: New Ehrlichia species emerges, hits United States. In Internal Medicine News Volume 39. Elsevier; 2006:48.

3. Yabsley MJ, Loftis AD, Little SE: Natural and experimental infection of white-tailed deer (Odocoileusvirginianus) from the United States with an Ehrlichia sp. closely related to Ehrlichiaruminantium. I Wildl Dis 2007 in press.

4. Allsopp BA, Bezuidenhout JD, Prozesky L: Heartwater. In Infectious Diseases of Livestock Volume 40. 2nd edition. Edited by: Coetzer JAW and Tustin RC. Cape Town, Oxford University Press; 2005:507-535.

5. Jongejan F, Morzaria SP, Shariff OA, Abdalla HM: Isolation and transmission of Cowdria ruminantium (causal agent of heartwater disease) in Blue Nile Province, Sudan. Vet Res Commun 1984, 8: 141-145.

6. Van de Pypekamp HE, Prozesky L: Heartwater. An overview of the clinical signs, susceptibility and differential diagnoses of the disease in domestic ruminants. Onderstepoort J Vet Res 1987, 54:263-266.

7. Yunker CE: Heartwater in sheep and goats: a review. Onderstepoort J Vet Res 1996, 63: 159-170.

8. Barre N, Uilenberg G, Morel PC, Camus E: Danger of introducing heartwater onto the American mainland: potential role of indigenous and exotic Amblyomma ticks. Onderstepoort J Vet Res 1987, 54:405-4I7.

9. Burridge MJ, Simmons LA, Peter TF, Mahan SM: Increasing risks of introduction of heartwater onto the American mainland associated with animal movements. Ann N Y Acad Sci 2002, 969:269-274.

10. Peter TF, Burridge MJ, Mahan SM: Ehrlichia ruminantium infection (heartwater) in wild animals. Trends Parasitol 2002, 18:214-218.

II. Inokuma H, Brouqui P, Drancourt M, Raoult D: Citrate synthase gene sequence: a new tool for phylogenetic analysis and identification of Ehrlichia. J Clin Microbiol 200I, 39:303 I-9.

12. Reddy GR, Sulsona CR, Harrison RH, Mahan SM, Burridge MJ, Barbet AF: Sequence heterogeneity of the major antigenic protein I genes from Cowdria ruminantium isolates from different geographical areas. Clin Diagn Lab Immunol 1996, 3:417-422.

13. Fleetwood SC, Teel PD, Thompson G: Seasonal activity and spatial distribution of lone star tick populations in east central Texas. Southwestern Entomologist 1984, 9:109-1 I6.

14. Mixson TR, Campbell SR, Gill JS, Ginsberg HS, Reichard MV, Schulze TL, Dasch GA: Prevalence of Ehrlichia, Borrelia, and rickettsial agents in Amblyomma americanum (Acari: Ixodidae) collected from nine states. J Med Entomol 2006, 43: | 26|-| 268.

15. Stromdahl EY, Evans SR, O'Brien J], Gutierrez AG: Prevalence of infection in ticks submitted to the human tick test kit pro- gram of the U.S. Army Center for Health Promotion and Preventive Medicine. J Med Entomol 200I, 38:67-74.

16. Peixoto CC, Marcelino I, Vachiery N, Bensaid A, Martinez D, Carrondo MJT, Alves PM: Quantification of Ehrlichia ruminantium by real time PCR. Vet Microbiol 2005, 107:273-278.

17. Burket CT, Vann CN, Pinger RR, Chatot CL, Steiner FE: Minimum infection rate of Ambylomma americanum (Acari: Ixodidae) by Ehrlichia chaffeensis (Rickettsiales: Ehrlichieae) in southern Indiana. J Med Entomol 1998, 35:653-659.

18. Long SW, Pound JM, Yu XJ: Ehrlichia prevalence in Amblyomma americanum, Central Texas. Emerg Infect Dis 2004, 10:1342-1343.

19. Peter TF, Barbet AF, Alleman AR, Simbi BH, Burridge MJ, Mahan SM: Detection of the agent of heartwater, Cowdria ruminantium, in Amblyomma ticks by PCR: validation and application of the assay to field ticks. J Clin Microbiol 2000, 38: I539-I544.

20. Childs JE, Paddock CD: The ascendancy of Amblyomma americanum as a vector of pathogens affecting humans in the United States. Annu Rev Entomol 2003, 48:307-337.

\section{Pre-publication history}

The pre-publication history for this paper can be accessed here:

\section{http://www.biomedcentral.com/1471-2334/8/54/prepub}

Publish with Biomed Central and every scientist can read your work free of charge

"BioMed Central will be the most significant development for disseminating the results of biomedical research in our lifetime. "

Sir Paul Nurse, Cancer Research UK

Your research papers will be:

- available free of charge to the entire biomedical community

- peer reviewed and published immediately upon acceptance

- cited in PubMed and archived on PubMed Central

- yours - you keep the copyright

Submit your manuscript here:

http://www.biomedcentral.com/info/publishing_adv.asp

BioMedcentral 